I acknowledge, with pleasure, the helpful advice and criticism of Dr S J. Rowland.

\title{
REFERENCES
}

Balch, C. C., Balch, D. A., Bartlett, S., Bartrum, M. P., Johnson, V. W., Rowland, S. J. \& Turner, J. (1955). F. Dairy Res. 22, 270.

Balch, C. C., Balch, D. A., Bartlett, S., Cox, C. P. \& Rowland, S. J. (1952). 7. Dairy Res. 19, 39. Balch, C. C., Balch, D. A., Bartlett, S., Cox, C. P., Rowland, S. J. \& Turner, J. (1954). F. Dairy Res. 2I, I65.

Balch, C. C., Balch, D. A., Bartlett, S., Hosking, Z. D., Johnson, V. W., Rowland, S. J. \& Turner, J. (1955). F. Dairy Res. 22, Io.

Balch, C. C., Johnson, V. W. \& Turner, I. A. (1955). Rep. Nat. Inst. Dairy. Reading, p. 40.

Balch, D. A. \& Rowland, S. J. (1957). Brit. F. Nutr. I1, 288.

Barry, J. M. (1958). Proc. roy. Soc. B, 149, 380.

Burt, A. W. A. (1957). Dairy Sci. Abstr. 19, 436 .

Folley, S. J. (1956). The Physiology and Biochemistry of Lactation. Edinburgh and London: Oliver and Boyd.

Glascock, R. F. (1958). Proc. roy. Soc. B, 149, 402.

Hilditch, T. P. (1956). The Chemical Constitution of Natural Fats, 3 rd ed. London: Chapman and Hall.

Knodt, C. B. (I94I). F. Dairy Sci. 24, 501.

Mann, A. I. \& Shaw, J. C. (r947). F. Dairy Sci. 30, I 83.

Masson, M. J. (195I). Research, 4, 73.

Malpress, F. H. (1945-6), Proc. R. Soc. Med. 39, 805.

McClymont, G. L. (1950). Aust. vet. F. 26, I I I.

McClymont, G. L. (1951a). Aust. F. agric. Res. 2, 92.

McClymont, G. L. (195Ib). Aust. F. agric. Res. 2, 158.

Pennington, R. J. (1957). Biochem. F. 65, 534.

Phillipson, A. T. (1952). Brit. F. Nutr. 6, 190.

Powell, E. B. (1938). Proc. Amer. Soc. Anim. Prod. p. 40.

Powell, E. B. (1939). F. Dairy Sci. 22, 453 .

Powell, E. B. (r94I). F. Dairy Sci. 24, 504.

Riddet, W., Campbell, I. L., McDowall, F. H. \& Cox, G. A. (x94I-2a). N.Z. F. Sci. Tech. 23, 80A. Riddet, W., Campbell, I. L., McDowall, F. H. \& Cox, G. A. (194I-2b). N.Z. F. Sci. Tech. 23, 99A. Rook, J. A. F. (1953). Proc. Nutr. Soc. 12, viii.

Rook, J. A. F. \& Rowland, S. J. (I959). Int. Dairy Congr. xv. London, I, 204.

Rowland, S. J. (1946). Dairy Ind. 11, 656.

Smith, J. A. B. \& Dastur, N. N. (1938), Biochem. J. 32, r868.

Tyznik, W. \& Allen, N. N. (1951). F. Dairy Sci. 34, 493.

Vallance, W. S. \& McClymont, G. L. (1959). Nature, Lond., 183, 466.

Van Soest, P. J., Allen, N. N. \& Maki, L. R. (1954). F. Dairy Sci. 37, 660.

Woodman, H. E. (1957). Bull. Minist. Agric., Lond., no. 48, 14th ed. p. 5 I.

\section{Some aspects of rumen ciliate protozoa}

\section{By J. Margaret Eadie, Rowett Research Institute, Bucksburn, Aberdeen}

The modern incentive for study of the rumen ciliates in relation to rumen function is not that the basic nature of their association with the ruminant is clearly understood but rather because of the one justified generalization: that certain species of ciliate have been found in the rumen of all normal adult ruminants so far examined. A study of their properties should therefore lead to a better understanding of the rumen as a whole. The comprehensive reviews of Hungate (r955) and Oxford (I955) cover the earlier work. I shall endeavour to discuss some of the more recent approaches to the subject. 
Study of the ciliate population in relation to the host

In general, diet appears to have the greatest effect upon the cilate population and variations in numbers are so large that no acceptable average figure can be given. The ration is not the only factor contributing to this variation, however, since even when a statistically accurate counting method was used on one sheep on a constant ration, the total population was $300000 / \mathrm{ml}$ one day and $\mathrm{I} 000000 / \mathrm{ml} 4^{8 \mathrm{~h}}$ later, (Boyne, Eadie \& Raitt, 1957). In order to follow significant trends in total or differential populations a great many figures would be required, and Moir and co-workers are at present studying this aspect (Moir \& Somers, 1956).

The wide variation in total population also prevents an accurate assessment of the average contribution of ciliate protein to the animal. Hungate (1955) estimates that it may be of the order of $20 \%$ of the protein requirement of the host. Qualitative studies of rumen microbial protein have suggested that the ciliate protein is of higher nutritional value than the bacterial protein when given to rats (McNaught, Owen, Henry \& Kon, I954), and Weller (I957), in estimates of the amino-acid content of protein from these two sources, has found more of the essential amino acids, particularly lysine, in the ciliate material.

Attempts have been made to compare ruminants free from ciliates with normal ruminants. Since the ciliates can only be transmitted by mouth contact, there being no known cyst forms, prevention of contamination is comparatively simple once the animal is free from protozoa. Becker, Schulz \& Emmerson (1930) defaunated goats chemically. Pounden \& Hibbs (1950) compared young animals that were prevented by isolation from establishing ciliates with others normally reared. Neither observed serious ill effects as a result of absence of ciliates although there was some indication that Pounden's unfaunated calves did not thrive as well as the controls.

It has frequently been assumed that early establishment of an adult flora and fauna in the young ruminant would lead to a more effective utilization of solid foodstuffs. Several workers have followed the establishment of ciliates in the normal young calf, most recently Bryant, Small, Bouma $\&$ Robinson (r958). They found no ciliates up to 13 weeks and only by 33-37 weeks were all the types they were following established. Pounden \& Hibbs (1948), who inoculated calves with adult rumen contents and reared them normally, found certain species established when the calves were between 3 and 6 weeks old. Work with calves under the early-weaning system of Preston (I 957) has shown that between 8 and 15 days an active mixed ciliate population may be established by inoculation, while milk and roughage alone are being fed, but when meal is subsequently added to the diet in large quantity the rumen contents become acid and the ciliates disappear only to become re-established very gradually 2--3 months later (Eadie, Hobson \& Mann, 1959). Pounden and co-workers in the U.S.A. (Pounden \& Hibbs, I950) and also New Zealand agriculturalists (e.g. McMeekan, 1954) favour a high-roughage diet in calf management. Recently an attempt was made to maintain the ciliates in the young early-weaned calf by continuing to feed a high proportion of roughage to meal. A preliminary trial with two calves has given the interesting result that the calves were unable to maintain themselves on the ration provided, although they were eating up well and had a thriving 
ciliate population (J. M. Eadie, P. N. Hobson \& S. O. Mann, unpublished observation). This observation clearly illustrates that a microbial picture typical of the adult is not the only vital factor in the ability to utilize solid food. By increasing the proportion of meal we hope to ascertain whether it is possible at this early age to give a milk-free diet suited both to the calf and the rumen ciliates.

\section{Study of the rumen ciliates in vitro}

In addition to variation in total ciliate population within and between ruminants, the species that make up this population vary. The ciliates may be subdivided into a considerable number of genera and species depending on the author of the classification. The picture is further complicated by the observation of several workers that certain previously described species may themselves vary. Hungate (1943) for example produced several 'species' from a clone of Entodinium simplex Dogiel. Lubinsky (1958) is at present attempting to clarify the classification.

Apart from the use of taxonomic features the ciliates may be roughly subdivided according to their diet, and from the point of view of rumen function this would seem to be a useful method.

By no means all rumen ciliates are observed to ingest cellulose although certain of the larger more conspicuous species do. Of these, Hungate (1942) has maintained Diplodinium neglectum Dogiel in vitro for 22 months, and Sugden (1953) kept cultures of the related species Metadinium medium Awerinzew \& Mutafowa for a shorter period. Another section of the larger ciliate population can be seen to ingest primarily green plant fragments and of these Epidinium ecaudatum Crawley has recently been cultured by Oxford (1958). In addition Bailey (1958) has used cell-free extracts to study the carbohydrases of this organism.

The rumen ciliates that, numerically at least, make up the largest proportion of most populations are the small Entodinium spp. It can be seen that these ciliates ingest plant fragments, starch, bacteria, or a mixture. The earliest culture work was carried out by Hungate (1943), who developed certain clone cultures. Coleman (I958) has kept a mixed culture for several months. The most systematic approach to maintaining Entodinium spp. in a defined medium and assessing the requirements for prolongation of life of the cultures has been the work of Kandatsu \& Takahashi (1955) in Japan. Their best culture required living rumen bacteria cultured apart from rumen liquor, a thermolabile factor produced by rumen bacteria, a thermostable factor derived from fresh clover leaves and vitamin $B_{12}$. Thus a completely defined medium seems still some way ahead, but progress has been made.

Finally, the group of organisms upon which the greatest volume of in vitro work has been done are the holotrich species Isotricha intestinalis Stein, I. prostoma Stein and Dasytricha ruminantium Schuberg, primarily noted for metabolism of soluble carbohydrates. These organisms can now be separated from rumen liquor and kept in washed suspensions fairly easily and have therefore received considerable attention. In addition, the separate genera have been kept isolated in cannulated sheep previously treated by the method of Eadie \& Oxford (1957). Oxford (1955) and Hungate (1955) discuss these species at considerable length. Though they make up 
only a small proportion of the ciliate population, Hungate estimated that they may contribute $10 \%$ of the total fatty acid produced in the rumen. Despite their relative morphological simplicity these ciliates have very active enzyme systems. Since 1955 Mould \& Thomas (I957) have published a study of the ciliate carbohydrates, and more recently Howard (x959a,b) has published two detailed papers in which the carbohydrate fermentative activities of the two genera are compared. It is interesting to note the considerable variation he found between genera.

Gutierrez (1958) published a further study of the ingestion of bacteria by holotrichous ciliates. This and further studies which he is carrying out on the association between the rumen bacteria and protozoa are of particular value since relatively little is known on this aspect (Appleby, Eadie \& Oxford, 1956).

\section{Conclusions}

Since Hungate and Oxford published their reviews work has progressed, but there remain many questions to be answered. Preliminary work with calves, even with those weaned on to a solid ration, shows that the presence of rumen ciliates does not appear to be an advantage and need not be an indication of health in the animal. Although the ciliate-free adult ruminants so far studied have shown no serious defects, it has yet to be ascertained whether a ciliate population would appear to be an advantage under conditions of stress, as opposed to controlled experimental management. Finally, in the separate study of the nutritional and biochemical properties of the ciliates, the volume of information so far obtained from a fairly thorough study of the holotrichous organisms suggests the potentialities of similar studies of the oligotrich ciliates and also clearly indicates the complexity of the combined activities of a rumen ciliate population.

\section{REFERENCES}

Appleby, J. C., Eadie, J. M. \& Oxford, A. E. (1956). F. appl. Bact. 19, I66.

Bailey, R. W. (1958). N.Z. F. agric. Res. I, 825 .

Becker, E. R., Schulz, J. A. \& Emmerson, M. A. (1930). Iowa St. Coll. F. Sci. 4, 215.

Boyne, A. W., Eadie, J. M. \& Raitt, K. (1957). F. gen. Microbiol. 17, 414.

Bryant, M. P., Small, N., Bouma, C. \& Robinson, I. (1958). F. Dairy Sci. 4r, 1747.

Coleman, G. S. (1958). Nature, Lond., 182, I 104.

Eadie, J. M., Hobson, P. N. \& Mann, S. O. (1959). Nature, Lond., r83, 624.

Eadie, J. M. \& Oxford, A. E. (1957). Nature, Lond., 179, 485.

Gutierrez, J. (1958). F. Protozool. 5, r22.

Howard, B. H. (1959a). Biochem. F. 71, 67 1.

Howard, B. H. (1959b). Biochem. F. 7r, 675 .

Hungate, R. E. (1942). Biol. Bull. 83, 303.

Hungate, R. E. (1943). Biol. Bull. 84, 157.

Hungate, R. E. (1955). In Biochemistry and Physiology of Protozoa. Vol. 2, p. I59. [S. H. Hutner and A. Lwoff, editors.] New York: Academic Press Inc.

Kandatsu, M. \& Takahashi, N. (1955). F. agric. chem. Soc. Fapan, 29, 833.

Lubinsky, G. (1958). Canad. 7. Zool. 36, 819.

McNaught, M. L., Owen, E. C., Henry, K. M. \& Kon, S. K. (1954). Biochem. F. 56, 151.

McMeekan, C. P. (1954). N.Z.F. agric. 88, 306.

Moir, R. J. \& Somers, M. (1956). Nature, Lond., I78, 1472.

Mould, D. L. \& Thomas, G. J. (r957). Biochem. F. 69, 327 .

Oxford, A. E. (1955). Parasitol. Rev. 4, 569.

Oxford, A. E. (1958). N.Z. F. agric. Res. 1, 809 .

Pounden, W. D. \& Hibbs, J. W. (I948). F. Dairy Sci. 3r, ro4r. 
Pounden, W. D. \& Hibbs, J. W. (1950). F. Dairy Sci. 33, 639.

Preston, T. R. (1957). N.A.A.S. Quart. Rev, no. 35, p. 18.

Sugden, B. (1953). F. gen. Microbiol. 9, 44.

Weller, R. A. (1957). Aust. F. biol. Sci. 10, 384 .

\title{
The treatment and prevention of bloat with anti-foaming agents
}

\author{
By C. S. W. ReID*, Plant Chemistry Division, D.S.I.R., \\ Palmerston North, New Zealand
}

Excessive frothing of the rumen contents during fermentation interferes with the normal elimination of gas. The effect appears to be due partly to its being trapped in a stable foam and partly to a direct inhibitory action of foam on eructation. There is strong evidence that acute pasture bloat is caused in this manner (for reviews, see Cole, Dougherty, Huffman, Hungate, Kleiber \& Maclay, I956; Johns, I956, 1958). The foaming agents in this instance appear to be the plant cytoplasmic proteins, possibly assisted by salivary mucoprotein (Mangan, 1959), and saponins and particulate matter may act as stabilizers.

A certain amount of foam is usually present in the rumen. Bloating is therefore a matter of degree; but why the change from mild to excessive foaming takes place is not yet fully understood. Further, although foaming may initiate the disorder, in the later stages secondary complications may occur, presumably originating as physiological reactions of the animal to inflation of the rumen.

If bloat is the consequencc of foaming, the administration of anti-foaming agents should be effective in both treatment and prevention. This paper reviews work carried out in New Zealand on the use of these substances in the treatment and prevention of acute bloat in grazing dairy cattle.

\section{Treatment}

Administration of anti-foaming agents was the only consistently useful treatment found (Johns, 1954; Reid \& Johns, I957 and unpublished results). A wide variety of fats and oils, as well as certain detergents and other synthetic surface-active substances, were effective, but some detergents were almost valueless, and all silicone preparations were unreliable.

After administration of an anti-foaming agent to a bloated animal, there may be little immediate effect, then deflation occurs over a relatively short time. This apparent latent period, which is quite variable, is important because it represents a substantial proportion of the time taken to give relief. Its cause is not yet known, but three possibilities are: variations in the strength of the foam; the rate of dispersion of the agent through the ingesta; or the necessity to clear a particular region, presumably the cardia. Dispersion would certainly offer some difficulty, since the foam is not usually in a discrete layer or block, but intimately mixed through the

\footnotetext{
* Present address: Physiological Laboratory, University of Cambridge.
} 